\title{
住宅における生活行為の評価と温熱環境の季節変化に関する研究 A STUDY ON ACTIONS OF DAILY LIFE AND SEASONAL CHANGE OF THERMAL ENVIRONMENT IN HOUSE
}

\author{
高 娟 淑*, 久野 覚**, 原田昌幸***, 中山和美****, 飯 村 龍***** \\ Younsuk KO, Satoru KUNO, Masayuki HARATA, \\ Kazumi NAKAYAMA and Ryo IIMURA
}

\begin{abstract}
The purpose of this study is to discern the actions of daily life and their relationship to environmental conditions in the LDK space of a house. The results were as follows; According to factor analysis, daily actions can be explained with three factors: "Relaxation and Concentration", "Working" and "Folding of laundry". Evaluation of "Relaxation and Concentration" and "Folding of laundry" factors are influenced by the change of thermal environment relative to a given season. Evaluation of "Working" factor is affected primarily by the relative characteristic of respective places and its thermal environment. When an air conditioner is used, evaluation of the act of the first factor "Relaxation and concentration" was heightened in living room sofa and dining chair, regardless of the season. As natural ventilation in summer and solar radiation in winter are a given in indoor settings, evaluation at living room floor or stairs might hold added value.
\end{abstract}

Keywords : House, Actions of daily life, Selection of place, Seasonal Change, Natural Ventilation, Solar radiation 住宅，生活行為，場所の選択，季節変化，通風，日射

\section{1. はじめに}

日本の伝統住宅では、夏には通風を、冬には日射を取り入れ、涼 と暖を得て快適感をもたらす住まい方をしていた。ところが、近年 の冷暖房技術、高断熱・高気密技術の発展により、暑さと寒さを感 じさせない快適な物理環境が確立され、年間を通して中立環境で生 活できるようになった。一方、最近の環境問題への関心から、ある 程度の快適な生活を維持しながら、省エネルギー的生活を実現する ことが重要とされるようになってきた。そのためには、特にエネル ギー消費量が増加する夏季と冬季に自然環境要素をさらに室内空間 に取り入れ、冷暖房に頼らず過ごせる室内環境作り出すことが重要 である。

一方、住宅では様々な生活行為が行われており、「住宅内の快適性 を向上させるためには、室内物理環境の改善だけではなく、生活行 為をその場所で快適に行うことができるか」など、それぞれの「場 所」の特性を把握する必要がある。

冷暖房を使用することにより、室内全体がほぼ均質な環境となっ ているのであれば、より快適に行為が行える場所をその都度変える 必要はないが、自然環境要素を取り入れた室内空間においては、季 節や時刻によって場所の特徴が変化するので、より快適に行為を行 える場所が変化する可能性がある。例えば、夏季は通風の影響によ り涼しく感じる場所、冬季には日射の影響により暖かく感じる場所
を選択し、行為を行うことができる。また、行為を行える場所が増 えることにより、場所の移動とともに場所を楽しむことができる。 つまり、自然環境要素を取り入れた室内空間では、その時々によっ て、それぞれの生活行為に応じた場所を選択することにより、冷暖 房に頼らなくても快適で省エネルギー的生活を行うことができる。

これまでに、住宅における生活行為に関する研究が、建築計画分 野において数多く行われている。例えば、宇野ら ${ }^{1)}$ は、北海道の戸 建住宅における公室空間について、居間では多くの生活行為が行わ れており、作業的行為や家事的行為は他の適切な受容空間を用意す べきであることを示している。また、森ら ${ }^{2)}$ は、食生活における食 空間の使い方について報告している。さらに、沖田ら ${ }^{3)}$ は、住宅そ れぞれの空間で実際にどのような生活行為が行われているかにつ いて分析することにより住戸タイプと地域においての空間の使わ れ方について検討している。

他方、建築環境工学の視点からは、冬季住宅の室内物理環境の調 査と居住者の意識や住まい方に関寸る研究報告が幾つかなされて いる。例えば、澤地ら ${ }^{4}$ は、関東地方の戸建・集合住宅を対象とし、 室内気候と居住者の生活行為について調査している。Sawashima, T. and Matsubara, N. ${ }^{5}$ は屋内の熱環境と温度環境調節行為には 時間を過ごす最良の場所を選べることが重要であることを示して いる。また、松原, 澤島 ${ }^{6}{ }^{6}$ は、住まい方である起居様式と寒さとの

\footnotetext{
$*$ 済州大学校生活環境福祉学部 非常勤講師 $\cdot$ 博士 (工学)

** 名古屋大学大学院環境学研究科 教授. 工博

*** 名古屋市立大学芸術工学研究科 准教授 $\cdot$ 博士 (工学 $)$

***** 東京電力(侏) 主任研究員・博士 (工学)

****** 東京電力(侏) 修士(工学)

Lecturer, Faculty of Human Ecology \& Welfare, Jeju National Univ., Dr. Eng.

Prof., Graduate School of Environmental Studies, Nagoya Univ., Dr. Eng.

Assoc. Prof., Graduate School of Design \& Architecture, Nagoya City Univ., Dr. Eng.

Tokyo Electric Power Company, M. Eng.

Tokyo Electric Power Company, M. Eng.
} 
関係についての報告している。さらに、澤島, 松原 ${ }^{7)}$ は京都市近辺 地域の住宅を対象として、室温や居住者の生活行為を観察した結果、 住宅の断熱・気密性能や室内温熱環境が冬期における居間での生活 行為と滞在時間に影響を与えることを示した。加藤ら ${ }^{819)}$ も長野市 の戸建住宅を中心として断熱気密性能の違いによる室内温熱環境 と居住者意識の差を比較し、冬季と夏季の差を明らかにしている。 ところが、国内外を通じ、自然環境を取り入れた室内空間において、 年間を通じた、場所と行為の関係に関寸る研究はほとんどないのが 実情である。

そこで、本研究では、自然環境要素として夏季の「通風」と冬季 の「日射」を積極的に取り入れたモデルハウスの LDK 空間を対象 に、主婦が日常行う「生活行為」と住宅の LDK 内の「場所」と温 熱などの環境条件との関係を明らかにすることを目的に、夏から冬 にかけて複数回の被験者実験と物理環境測定を行った。既報 ${ }^{10)}$ では、 LDK 空間における季節の温熱環境評価の特性を把握し、夏季の「通 風」や冬季の「日射」が、それぞれの場所における温熱的快適性に 及ぼす影響について報告した。本報では、生活行為の評価と場所と の関係に着目し、生活行為の特徵を分類 - 整理、その生活行為と場 所との関係、季節による場所ごとの温熱環境の変化が行為の評価に 及ぼす影響について報告する。

\section{2. 実験概要}

本研究で実験に用いた空間は、快適性と省エネルギー性を両立さ せた理想的な暮らしを目指して建てられた千葉県浦安市にある $\mathrm{T}$ 社の環境共生型モデルハウスの LDK 空間である。モデルハウスの 1 階平面図及び物理環境測定位置、被験者心理評価位置、空位置を 図 1 に示寸。浦安は海から吹いてくる風の影響を受けやすく、日中 の風向は年間を通じ南南西と北東が卓越している地域である。その ためモデルハウスの計画は、敷地周辺の障害物などを考慮し、開口 を南側（面積 $22.8 \mathrm{~m}^{2}$ ) と北側に大きく設け、風がよく通るように なっている。また、日射を遮蔽するため、建物の南面と南西面につ たかずら落葉植物を用いた窓面・壁面緑化を行っており、より多く の太陽エネルギーを取り入れるために、一階の天井を高く $(\mathrm{h}=3.55 \mathrm{~m})$ 、南向きのリビング密を大きくし $(\mathrm{h}=3.55 \mathrm{~m}) 、$ 床の仕 上げには集熱効果を見込んで黒色の玄昌石が用いられている。また、 断熱性能を高めるため、高性能ガラス・サッシを使用し、次世代省 エネルギー基準を満たす設計となっている。

実験期間と被験者属性および実験条件を表 1 に示す。実験は、 2007 年 8 月、 9 月、 10 月、 12 月と 2008 年 1 月の 5 期に、各期 2 $\sim 4$ 日間行った。被験者は、 8 月、 9 月、 12 月、 1 月に女子大学生 を、10 月に一般の主婦を 1 日 4 人ずつ（一部 2 人ないし 5 人）採 用した。被験者には、家で長時間過ごす主婦を想定したが、毎回主 婦を採用して実験を行うことが難しかったため、代わりに女子大学 生を採用した。また、各期の実験日の参加者は、毎回異なる被験者 が参加したが、一部の被験者は複数の期の実験に参加した。実験の 条件は、自然通風（空の開け方は 3 種類）、エアコン使用、空閉鎖、 合計 3 条件で実験を行った。自然通風時の条件は、南方向からの風 がよく通るように、図 1 の空(1)、空(11)、空(7)、空(5)、空(4)の開け幅 を、実験日の気象条件により適宜調節した。8月は、自然通風条件 とエアコン条件がある。気温は高いが、エアコンを使用しなくても
通風で過ごせると思うときは自然通風条件とした。10 月は、自然 通風条件と空閉鎖条件があるが、空を開けた場合寒いと思われると きは空閉鎖条件とした。1月は空閉鎖条件とエアコン条件があるが、 日射があり、エアコンを使用しなくてもある適度室温が高い場合は 空閉鎖条件とした。

表 2 に、実験日ごとの各時間帯の屋外における測(10の気温と湿度、 全天空照度の平均值を示す。各季節の気温は、8月は $30.4^{\circ} \mathrm{C} \sim 32.8^{\circ} \mathrm{C} 、$

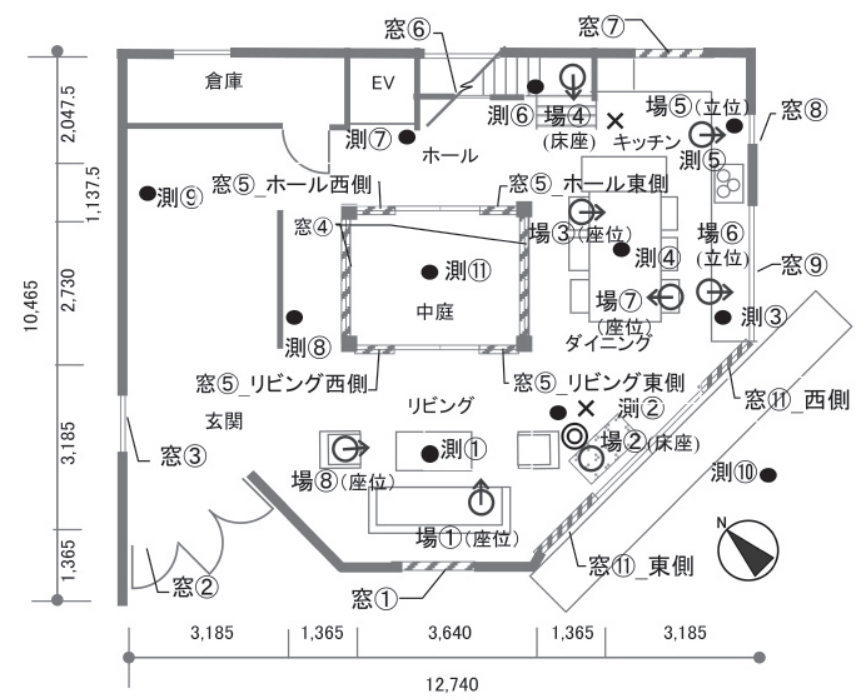

ア : 被験者心理評価位置および向き ○) メ : 風速計・グローブ温度測定位置 温熱環測定位置

V/ : 開閉させる空位置

図 1 モデルハウスの 1 階平面図及び物理環境測定位置 表 1 実験期間と被験者属性及び実験条件

\begin{tabular}{|c|c|c|c|c|c|c|}
\hline & \multirow{2}{*}{ 実験期間 } & \multicolumn{2}{|c|}{ 被験者 } & \multicolumn{2}{|c|}{ 空条件 } & \multirow{2}{*}{ 照明条件 } \\
\hline & & 人数 & 属性 & 11時 & 14時 & \\
\hline \multirow{3}{*}{$\begin{array}{c}\text { 8月 } \\
\text { (酷暑期) }\end{array}$} & $2007 / 08 / 21$ & 4人 & \multirow{3}{*}{$\begin{array}{l}\text { 女子大学生 } \\
(19 \sim 23 \text { 歳 })\end{array}$} & 空条件 I & 悹条件 I & \multirow{3}{*}{$O F F \cdot O$} \\
\hline & $2007 / 08 / 22$ & 4人 & & 空条件 I & エアコン & \\
\hline & $2007 / 08 / 24$ & 4人 & & 空条件 I & エアコン & \\
\hline \multirow{2}{*}{$\begin{array}{c}\text { 9月 } \\
\text { (冷房端境期) }\end{array}$} & $2007 / 09 / 26$ & 4人 & \multirow{2}{*}{$\begin{array}{l}\text { 女子大学生 } \\
(21 \sim 22 \text { 歳 })\end{array}$} & 空条件 I & 空条件 I & \multirow{2}{*}{$O F F \cdot O$} \\
\hline & $2007 / 09 / 27$ & 2 人 & & 空条件 I & 空条件 I & \\
\hline \multirow{4}{*}{$\begin{array}{c}\text { 10月 } \\
\text { (中間期) }\end{array}$} & $2007 / 10 / 16$ & 4人 & \multirow{4}{*}{$\begin{array}{c}\text { 主婦 } \\
(30 \sim 43 \text { 歳 })\end{array}$} & 空全閉鎖 & 空全閉鎖 & \multirow{4}{*}{ OFF.O } \\
\hline & $2007 / 10 / 17$ & 4人 & & 空条件 I & 空条件 I & \\
\hline & $2007 / 10 / 18$ & 4人 & & 窓条件 II & 窓条件 II & \\
\hline & $2007 / 10 / 19$ & 4人 & & 空全閉鎖 & 空条件 III & \\
\hline \multirow{2}{*}{$\begin{array}{c}\text { 12月 } \\
\text { (暖房端境期) }\end{array}$} & $2007 / 12 / 06$ & 5人 & \multirow{2}{*}{$\begin{array}{l}\text { 女子大学生 } \\
(18 \sim 24 \text { 歳 })\end{array}$} & 空全閉鎖 & 空全閉鎖 & \multirow{2}{*}{$O F F \cdot O$} \\
\hline & $2007 / 12 / 07$ & 4人 & & 空全閉鎖 & 空全閉鎖 & \\
\hline \multirow{4}{*}{$\begin{array}{c}\text { 1月 } \\
\text { (極寒期) }\end{array}$} & $2008 / 01 / 29$ & 4人 & \multirow{4}{*}{$\begin{array}{l}\text { 女子大学生 } \\
(19 \sim 23 \text { 歳 })\end{array}$} & エアコン & エアコン & \multirow{4}{*}{$O F F \cdot O$} \\
\hline & $2008 / 01 / 30$ & 4人 & & 空全閉鎖 & 空全閉鎖 & \\
\hline & $2008 / 01 / 31$ & 4人 & & 空全閉鎖 & 空全閉鎖 & \\
\hline & $2008 / 02 / 01$ & 5 人 & & 空全閉鎖 & 空全閉鎖 & \\
\hline
\end{tabular}

空条件 I : 空(1)、空(11)、空(7)、空(4)、空(5)在開放。他の空は閉銷

・空条件 II : 空(7)、空(11)閉鎖。他の空は開放。

・空条件III : 空(11) $(2 つ)$ をそれぞれ $30 \mathrm{~cm}$ 開放。他の空は開放。

・エアコン: 空は全て閉鎖し、エアコン 3 台を運転。 8 月 ; $26^{\circ} \mathrm{C} 、 1$ 月 ; $22^{\circ} \mathrm{C}$ 設定。

・空(4)：上部分は固定式、下部分の $30 \mathrm{~cm}$ のみ開けられる。

表 2 屋外の環境測定結果

\begin{tabular}{|c|c|c|c|c|c|c|c|}
\hline & \multirow{2}{*}{ 実験期間 } & \multicolumn{3}{|c|}{ 11時 } & \multicolumn{3}{|c|}{ 14時 } \\
\hline & & 外気温 $\left({ }^{\circ} \mathrm{C}\right)$ & 外湿度 (\%) & 全天空照度 (1x) & 外気温 ( $\left.{ }^{\circ} \mathrm{C}\right)$ & 外湿度 (\%) & 全天空照度 (Ix) \\
\hline \multirow{3}{*}{$\begin{array}{c}\text { 8月 } \\
\text { (酷暑期) }\end{array}$} & $\begin{array}{l}2007 / 8 / 21 \\
\end{array}$ & 31.4 & 55.9 & 33778 & 31.4 & 60.7 & 21831 \\
\hline & $2007 / 8 / 22$ & 32.8 & 53.5 & 20551 & 32.2 & 58.2 & 20590 \\
\hline & $2007 / 8 / 24$ & 30.4 & 53.8 & 50156 & 31 & 50.2 & 35400 \\
\hline \multirow{2}{*}{$\begin{array}{c}\text { 9月 } \\
\text { (冷房端境期) }\end{array}$} & $2007 / 9 / 26$ & 25.6 & 46.3 & 40078 & 25.9 & 42.1 & 30056 \\
\hline & $2007 / 9 / 27$ & 24.7 & 64.2 & 35406 & 24.5 & 72.9 & 19502 \\
\hline \multirow{4}{*}{$\begin{array}{c}10 \text { 月 } \\
\text { (中間期) }\end{array}$} & $2007 / 10 / 16$ & 17.3 & 73.1 & 8957 & 17.7 & 73.4 & 8426 \\
\hline & $2007 / 10 / 17$ & 22.2 & 51.2 & 27799 & 20.7 & 56.7 & 28262 \\
\hline & $2007 / 10 / 18$ & 21.2 & 53.3 & 22928 & 20.9 & 54.3 & 14443 \\
\hline & $2007 / 10 / 19$ & 22.9 & 40.2 & 31756 & 20.8 & 42 & 24487 \\
\hline \multirow{2}{*}{$\begin{array}{c}12 \text { 月 } \\
\text { (暖房端境期) }\end{array}$} & $2007 / 12 / 6$ & 20.6 & 25.9 & 15147 & 21.6 & 28.1 & 13869 \\
\hline & $2007 / 12 / 7$ & 21.1 & 29.1 & 15134 & 22.6 & 30.8 & 11842 \\
\hline \multirow{4}{*}{$\begin{array}{c}\text { 1月 } \\
\text { (極寒期) }\end{array}$} & $2008 / 1 / 29$ & 5.5 & 65.7 & 7966 & 5.5 & 68.1 & 4433 \\
\hline & $2008 / 1 / 30$ & 12.5 & 38.5 & 24001 & 13 & 35.5 & 20174 \\
\hline & $2008 / 1 / 31$ & 11.9 & 19 & 25499 & 12.8 & 17.6 & 10554 \\
\hline & $2008 / 2 / 1$ & 11.7 & 13.5 & 8737 & 13 & 13.1 & 9191 \\
\hline
\end{tabular}


表 3 行為評価の質問項目

\begin{tabular}{|c|c|}
\hline 行為の分類 & 評 価 尺 度 \\
\hline 休 媳 & 1 うたた寝をする 12 何もせずリラックスする \\
\hline 家 事 & 9 洗濯物をたたむ 11 料理の下ごしらえをする \\
\hline 視作業 & $\begin{array}{l}2 \text { 新聞を読む } 3 \text { 本を読む } 4 \text { 書き物をする } \\
5 \text { パソコンをする } 10 \text { 手芸·裁縫をする }\end{array}$ \\
\hline 楽 & 6 お茶をする 7 音楽鑑賞をする 8 長電話をする \\
\hline 思 考 & 13 考え事をする \\
\hline
\end{tabular}

評価尺度：11 段階（0 点；絶対にここではしたくない〜10 点 ; ぜひここでしたい）

表 4 物理環境測定項目の概要

\begin{tabular}{|c|c|c|c|}
\hline 測定機器 & 測定位置·高さ & 実測時間 & 測定間隔 \\
\hline 温湿度計 & 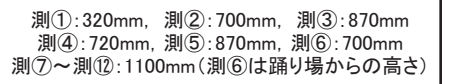 & 10時 15時 & 10秒 \\
\hline グローブ温度計 & キッチン, 空佃_東側付近 & 10時 15時 & 10秒 \\
\hline 熱線風速計 & 被験者位置(場(1) 場(8)，開散している空中央部 & 11時 ， 14時 & 1秒 \\
\hline 照度計 & 被験者位置(場(1) 場8) & 11時 ， 14時 & - \\
\hline
\end{tabular}

9 月は $24.5^{\circ} \mathrm{C} \sim 25.9^{\circ} \mathrm{C} 、 10$ 月は $17.3^{\circ} \mathrm{C} \sim 22.2^{\circ} \mathrm{C} 、 12$ 月は $20.6^{\circ} \mathrm{C} \sim$ $22.6^{\circ} \mathrm{C} 、 1$ 月は $5.5^{\circ} \mathrm{C} \sim 13^{\circ} \mathrm{C}$ であり、湿度は 8 月、9 月、10月は午 前と午後とも $40 \%$ ～ $60 \%$ 、12 月と 1 月は $40 \%$ 以下になっていた。 本研究では、主婦が日常行う生活行為として表 3 に示す 13 の項 目を取り上げる。休毠行為（1 うたた寝をする/12 何もせずリラッ クス寸る)、家事行為（9 洗濯物をたたむ $/ 11$ 料理の下ごしらえをす る)、視作業行為 $(2$ 新聞を読む $/ 3$ 本を読む $/ 4$ 書き物をする $/ 5$ パソ コンをする $/ 10$ 手芸・裁縫をする)、娛楽行為（6 お茶をする $/ 7$ 音 楽鑑賞をする $/ 8$ 長電話をする)、思考行為（13 考え事をする）の 5 種類の 13 行為注 1) である。行為の評価は、図 1 に示寸ようにあら かじめ設定したリビングのソファ (場 1)/場 (8) 、リビングの床（場 (2)）、ダイニングの椅子 (場(3/場(7) 、階段（場(4)）、キッチン（場 (5))、作業台（場(6)）の8つの場所において、実際に座ったりせず、 フロアを順に歩き回ってもらい、回答してもらった注 2 。 00 点の「絶 対にここではしたくない」から 10 点の「ぜひここでしたい」まで の 11 段階で評価させた。被験者には、「あなたはこのモデルハウス に住んでいる主婦であり」、主人と子供は出かけていて家には 1 人 でいる」という設定で実験に臨んでもらった。午前の実験は主婦が 朝の掃除、洗濯などを終えた時間帯として 11 時から、午後の実験 は昼食の片付けを終えた時間帯として 14 時から、それぞれ 60 分か ら 75 分かけて行った。心理評価を行う前に、実験手順の確認と評 価に慣れるため、異なるフロアで実験説明と練習を行った。

表 4 に、物理環境測定項目の概要を示寸。物理環境測定点は図 1 に示すように被験者評価場所の付近に測(1)から測(6)、その他として 住宅内の測(7)と測 (9)、屋外の測(10)測(11)である。温湿度・グローブ 温度は 10 秒間隔で自動計測し、風速は移動計測で被験者の頭の付 近において 1 秒間隔で 60 秒間測定し、平均值を求めた。室内照明 は OFF と ONの 2 条件で、それぞれの場所の作業面照度を、全天 空照度は屋外の開けた駐車場での照度を、各時間帯の実験の開始前、 中間、終了後に測定した。

\section{3. 生活行為評価の因子分析の結果}

\section{1 生活行為の因子分析}

住宅 LDK の 8 つの場所に対して、これらの場所の持つ行為とし ての潜在的な特徵を明らかにし、室内空間における各場所と生活行
表 5 生活行為評価項目の因子分析 (全季節)

因子負荷量 : 回転後 (バリマックス法)

\begin{tabular}{|l|c|c|c|}
\hline \multirow{2}{*}{ 行為項目 (13行為) } & 第 1 因子 & 第 2 因子 & 第 3 因子 \\
\cline { 2 - 4 } & リラックス·集中 & 作業 & 洗濯物をたたむ \\
\hline 何もせずリラックスする & 0.885 & 0.087 & 0.371 \\
\hline 長電話をする & 0.874 & 0.074 & 0.102 \\
\hline 考え事をする & 0.842 & 0.278 & 0.066 \\
\hline 音楽鑑賞をする & 0.839 & 0.076 & 0.384 \\
\hline 本を読む & 0.817 & 0.414 & 0.202 \\
\hline うたた誛をする & 0.786 & 0.202 & 0.455 \\
\hline お茶をする & 0.659 & 0.619 & 0.235 \\
\hline 書き物をする & 0.153 & 0.949 & -0.005 \\
\hline パソコンをする & 0.294 & 0.892 & 0.061 \\
\hline 料理の下ごしらえをする & -0.070 & 0.887 & -0.048 \\
\hline 手芸·裁縫をする & 0.506 & 0.643 & 0.384 \\
\hline 新聞を読む & 0.617 & 0.634 & 0.255 \\
\hline 洗濯物をたたむ & 0.341 & 0.006 & 0.764 \\
\hline 二乗和 & 5.546 & 3.990 & 1.406 \\
\hline 寄与率 & $42.66 \%$ & $30.69 \%$ & $10.81 \%$ \\
\hline 累積寄与率 & $42.66 \%$ & $73.35 \%$ & $84.16 \%$ \\
\hline
\end{tabular}

* 因子負荷量 0.600 以上にあみ掛け

為との関係をとらえるため、各季節における実験日ごとに実験時間 帯別、照明条件別で求めた被験者の申告值の平均を用いて、因子分 析（主因子法、バリマックス回転）を行った。その結果、固有值 1.0 までで 3 つ因子が抽出された。表 5 に因子負荷量と寄与率を示す。

\section{2 生活行為の因子負荷量}

表 5 より、生活行為は 3 つの因子で説明できることがわかった。 第 1 因子の負荷量が大きい行為は、休䕀行為である「何もせずリラ ックス寸る/うたた寝をする」、娛楽行為である「長電話をする/音楽 鑑賞をする/お茶をする」のリラックスとの関係が強い行為と、思考 行為である「考え事をする」、視作業行為の中で「本を読む/新聞を 読む」の集中との関係が強い行為であり、第 1 因子は『リラックス・ 集中』の因子と考えることができる。リラックスと集中は全く性格 の異なる行為であると思われたが、場所との関係においては、1つ の潜在的な因子を形成する結果となった。第 2 因子は、視作業行為 の中で（書き物をする/パソコンをする/手芸・裁縫をする/新聞を読 む」、家事行為の中で「料理の下ごしらえをする」、娛楽行為の中で 「お茶をする」などで因子負荷量が大きく、『作業』の因子と考える ことができる。第 3 因子は、家事行為である「洗濯物をたたむ」の 行為のみが因子負荷量が高く、『洗濯物をたたむ』行為は、他の行為 とは異なる特徵を持つことがわかった。娛楽行為の「お茶をする」 と視作業行為の「新聞を読む」は、第 1 因子と第 2 因子の 2 つの特 徵を持っている。

\section{3 場所と生活行為評価の因子得点との関係}

生活行為と各場所の関係を明らかにするため、因子得点布置図を 描いた（図 2 と図 3)。図の中の各点は、6つの場所注 3) の季節別、 実験日別、時間帯別（11 時と 14 時）、照明条件別（OFF と ON） の因子得点を示している。

まず、第 1 因子の『リラックス・集中』と場所との関係を見ると、

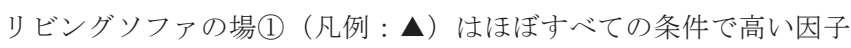
得点となっていたが、残る $5 つ$ 場所は実験条件によって正の值か ら負の值まで幅広い得点分布となっている。このことは、第 1 因子 の『リラックス・集中』の性質を持つ行為は、特定の場所が好まれ 
たり嫌われたりするというよりも、同じ場所であっても環境の状態 によって好まれるか嫌われるかが変化することを示している。

これに対して、第 2 因子の『作業』と場所との関係を見ると、得 点の值は、場所によってほぼ決まっている。最も因子得点が高い場 所はダイニング椅子の場(3)と場(7)であり、続いて、リビングソファ の場(1)と場(8)、次に、リビング床の場(2)、最も得点の值が低いのは 階段の場(4)である。このことは、第 2 因子の『作業』の性質を持つ 行為は、それぞれの場所の環境状態が多少異なってもその場所の評 価はあまり変化せず、特定の場所が好まれることがわかる。

第 3 因子の『洗濯物をたたむ』と場所の関係を見ると、最も得 点が高い場所はリビング床（場(2)）で、最も低い場所は階段 (場(4) となっており、リビングソファ (場(1)と場 (8) ) とダイニング椅子 (場 (3) と場(7) はほぼ同じであるが、リビングソファの 2 つの場所の得 点がやや高い。第 3 因子の性質を持つ行為は場所によって因子得点 の值がほぼ決まっており、好まれる場所が明確である点は、第 2 因 子と同じであるが、第 2 因子の場合と比べると、第 3 因子の方が同 じ場所での因子得点のばらつきの幅が大きい。

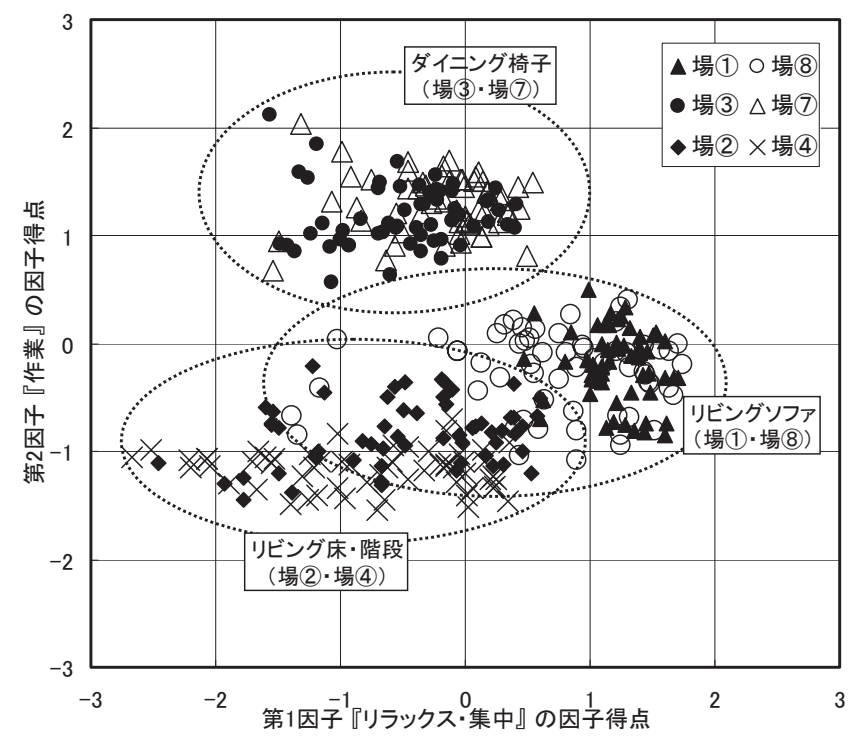

図 2 因子得点布置図（因子 $1 \times$ 因子 2 )

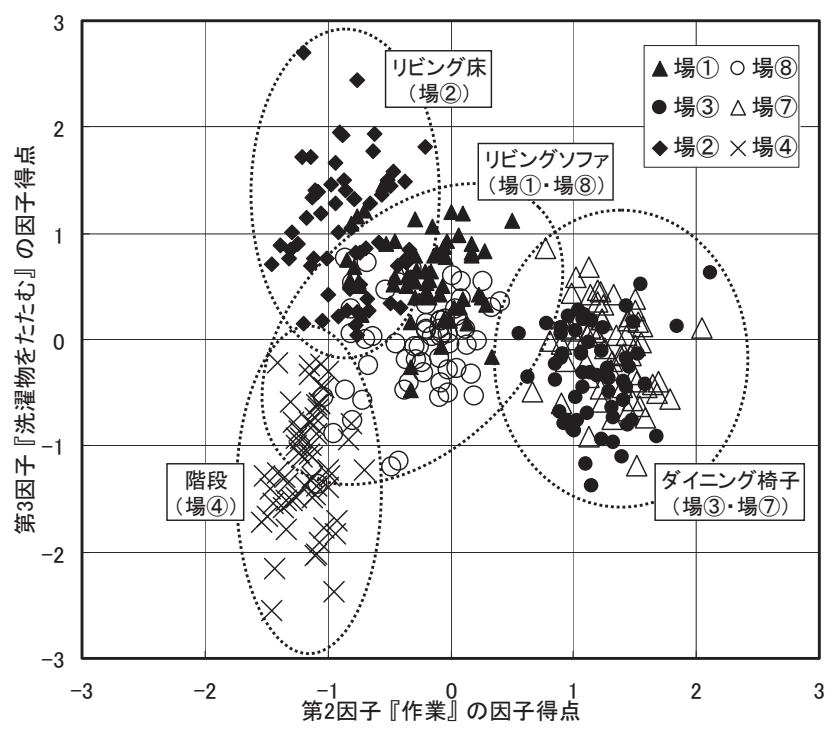

図 3 因子得点布置図（因子 $2 \times$ 因子 3 ）

\section{4. 季節における生活行為評価の因子得点の特徵}

前章の分析によると、第 2 因子『作業』の因子得点は、場所によ る違いがはっきり見られ、同一の場所における因子得点は似た值を とるのに対して、第 1 因子『リラックス・集中』と第 3 因子『洗濯 物をたたむ』の得点では、幾つかの場所において同一の場所にも関 わらず、実験条件、すなわち、物理環境の違いによって因子得点の 值が大きく異なり、物理環境の違いが行為の評価に影響を及ぼすこ とが示唆された。そこで、実験条件によって因子得点に比較的大き な違いが見られた第 1 因子に対して、リビングソファ (場 (8))、ダ イニング椅子 (場(3)と場(7))、リビング床（場(2)）と階段（場(4)）に ついて、物理環境条件と因子得点との関係について検討した。その 結果、照度との間には明確な関係がみられなかった注 4) が、気温な どの温熱指標との間には関係が見られた。そこで、ここでは、温熱 環境指標の SET*を用いて季節における生活行為の因子得点の特徵 について分析する。図の各点は、各季節の実験条件ごとの被験者 4 人（一部 2 人または 5 人）の評価平均值であり、少人数の平均であ るが、全体として条件ごとの生活行為の評価の傾向がうかがえる。

(1) リビングソファ

リビングソファ（場(1)と場 (8)）における第 1 因子『リラックス・ 集中』の因子得点と SET*との関係を図 4 に示す。まず、図 4 の工 アコンを使用した 8 月（凡例： $\square ） と 1$ 月（凡例：○）について見 ると、 2 人掛けソファの場(1)も 1 人掛けソファの場(8)も因子得点は いずれも高く、冷暖房使用時は行為の評価があまり変化しないこと が分かる。次に、空閉鎖の 10 月（凡例： $\mathbf{\Delta ） と ~} 12$ 月（凡 例： + ）
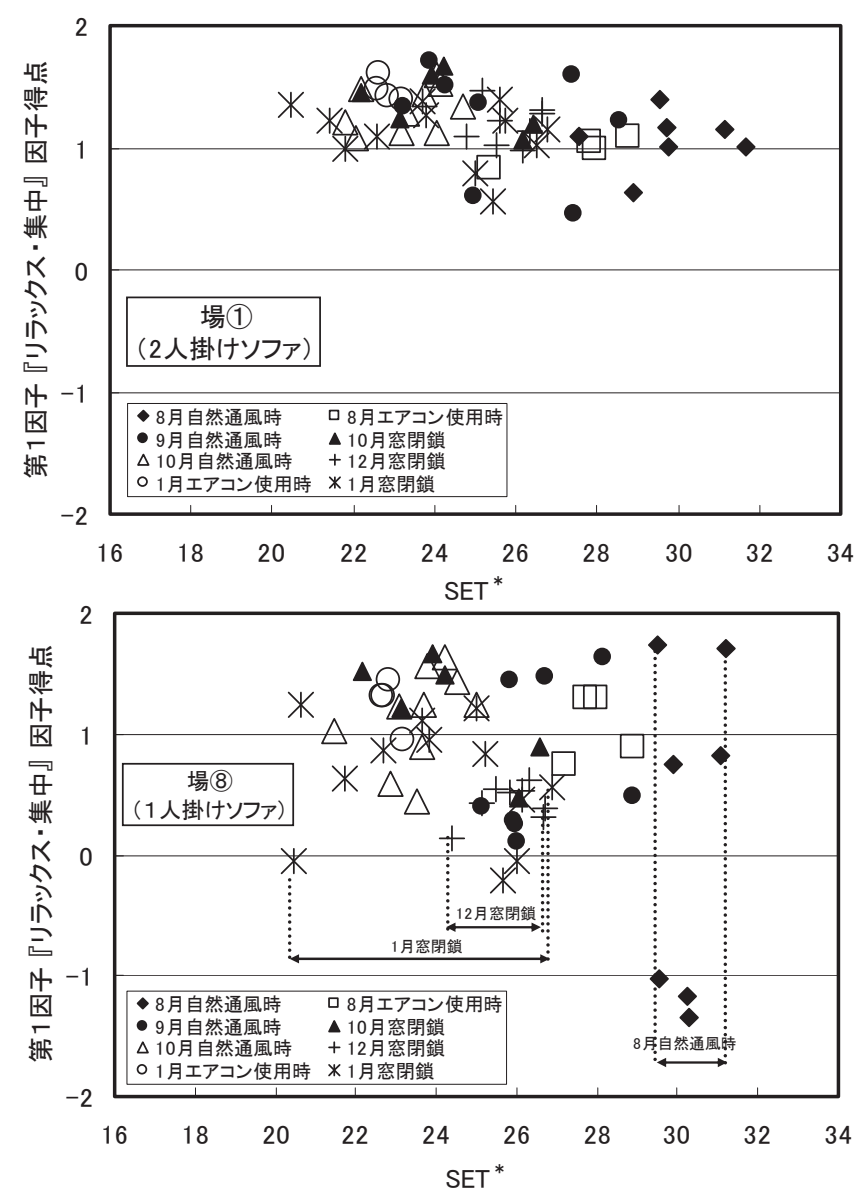

図 4 SET*と第 1 因子得点との関係（場(1)と場(8)） 
と 1 月（凡例：*）について見ると、 2 人掛けソファの場(1)ではい ずれも高い因子得点をとっているのに対して、1 人掛けソファの場 (8)では 10 月、 12 月、1 月と季節が秋から冬になるにしたがって、 より低い因子得点をとる条件が増える傾向が見られる。場(1) と場 (8) の気温は、リビングテーブル上（測(1)）の 1 ケ所の測定值で代表さ せているが、 12 月と 1 月の空閉鎖条件は天気が良く、エアコンを使 用寸る必要がない条件であり、リビングの南西の空からは日射が入 り、その日射の影響により、南西の空に近い 2 人掛けソファ場 (1) 空から遠い 1 人掛けソファ場 (8)で温熱環境が異なり、場 (8)が幾分寒 い環境であったことが因子得点の違いとなった要因と考えられる。

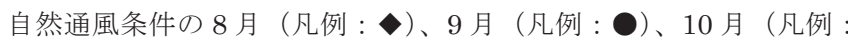
$\triangle$ ）について見ると、場(8の 9 月と 10 月は、場(1)に比心゙、やや因 子得点が低い条件があるものの、ほぼ同程度であるが、場(8)の 8 月 は因子得点が高い条件がある一方で、非常に低い点が複数存在する。

以上の結果より、冷暖房を使わずに自然環境を取り入れた時は、 同じ季節でも日によって場所の温熱環境が異なり、行為の評価も変 わる可能性がある。

\section{（2）ダイニング椅子}

図 5 に、ダイニング椅子（場(3)と場(7)）における第 1 因子の因子 得点と SET*との関係を示す。エアコンを使用した 8 月と 1 月に注 目すると、ダイニング椅子（場(3)と場(7)）では因子得点が相対的に 高い值で固まるように布置している。これは、リビングソファにお ける特徵と同じである。次に、空閉鎖条件の 10 月、12 月、 1 月に ついて見ると、場(3)、場(7) ともにエアコン条件に比心゙、因子得点の ばらつきはやや大きくなっている。また、これらはほぼ一定の值を
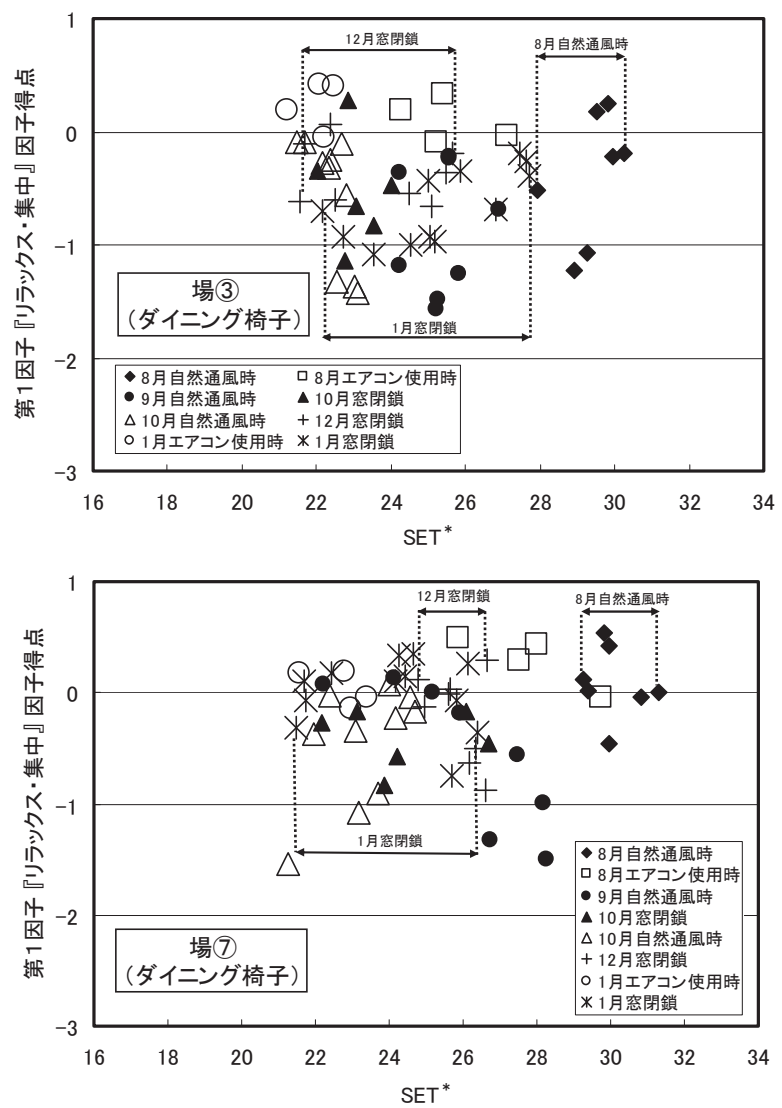

図 5 SET*と第 1 因子得点との関係（場(3)と場(7)）
とっており、2つの場所の間に大きな違いはなく、9月と 10 月の自 然通風条件より高い得点であった。ガラスの面積が大きい一般住宅 の場合、空のガラスの付近において、冬季は冷放射の影響をうける 可能性が高いが、このモデルハウスでは超高断熱真空ガラスを採用 しており、それほど室内側のガラス面が冷えない。この冷放射の影 響をあまり受けないことが高評価の要因であると考えられる。違い を挙げるなら、1 月では場(3)に比べて、場(7)の得点が幾分高くなっ ている。場(7)はリビングの南空に近い場所であり、リビングソファ の場(1)と同様に冬季は日射の影響が評価を高めた可能性がある。

次に、自然通風条件を見ると、場(7)の 8 月の因子得点は相対的に 高い值である。両場所の 9 月、10月及び場(3)の 8 月の因子得点はば らついた分布となっており、場(3)、場(7)ともにこれらの場所での最 も低い因子得点をとる条件となっている。低い得点が見られる原因 について検討したところ、場(3)では見られなかったが、場(7)では風 速との関係が見られ、8 月、9 月には風速が高いことが評価を高め た一因であると考えられる。ダイニング椅子の 2 ケ所でもリビング ソファと同じように、ダイニングテーブル上の測(4)の 1 ケ所で測定 した気温で代表させているが、リビング南空に近い場(7)では夏季の 通風、冬季の日射の影響をより強く受け、異なる環境になり、因子 得点の違いとなったと思われる。

(3) リビング床

リビング床（場(2)）は階段（場(4)）とともに他の場所に比べ、第 1 因子『リラックス・集中』の因子得点が相対的に低い場所である がばらつきが大きく、条件によっては比較的高い得点をとるケース

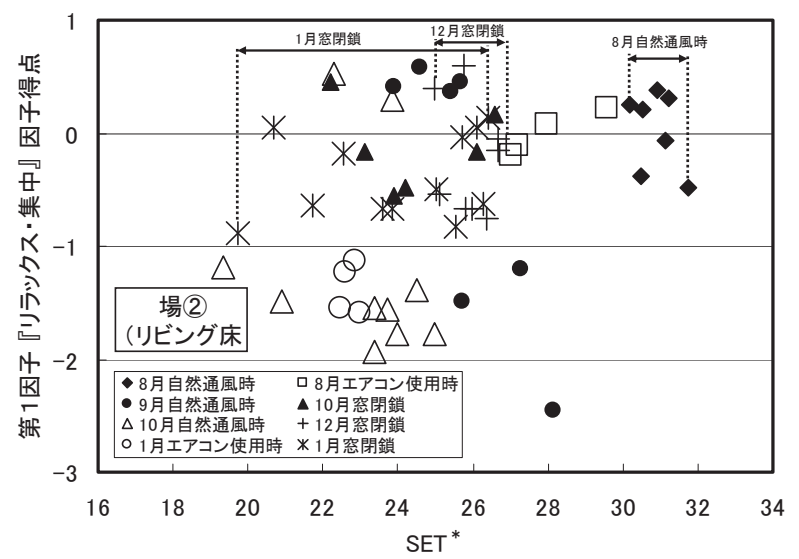

図 6 SET*と第 1 因子得点との関係（場(2)

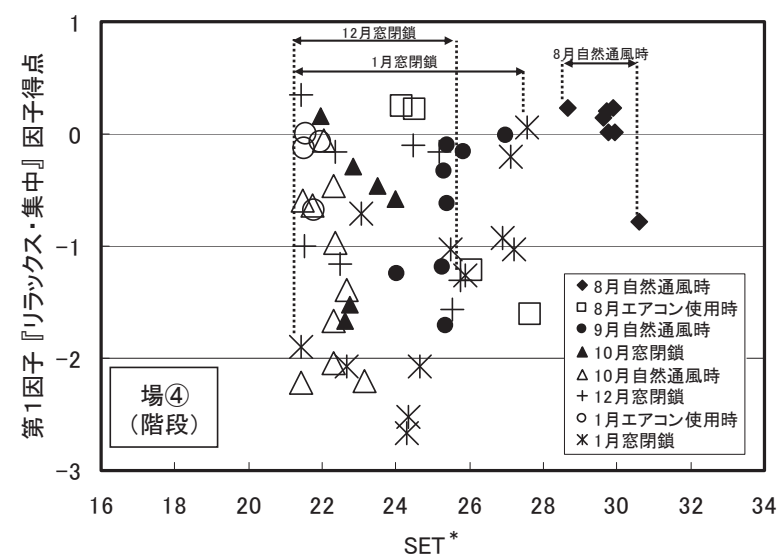

図 7 SET*と第 1 因子得点との関係（場(4) 


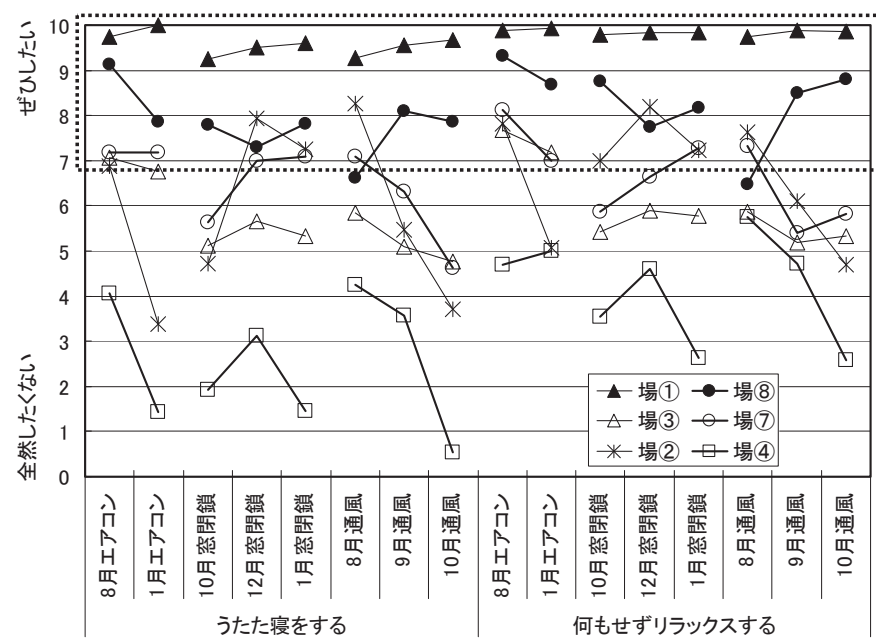

(a) 第 1 因子の『リラックス』の休憩行為

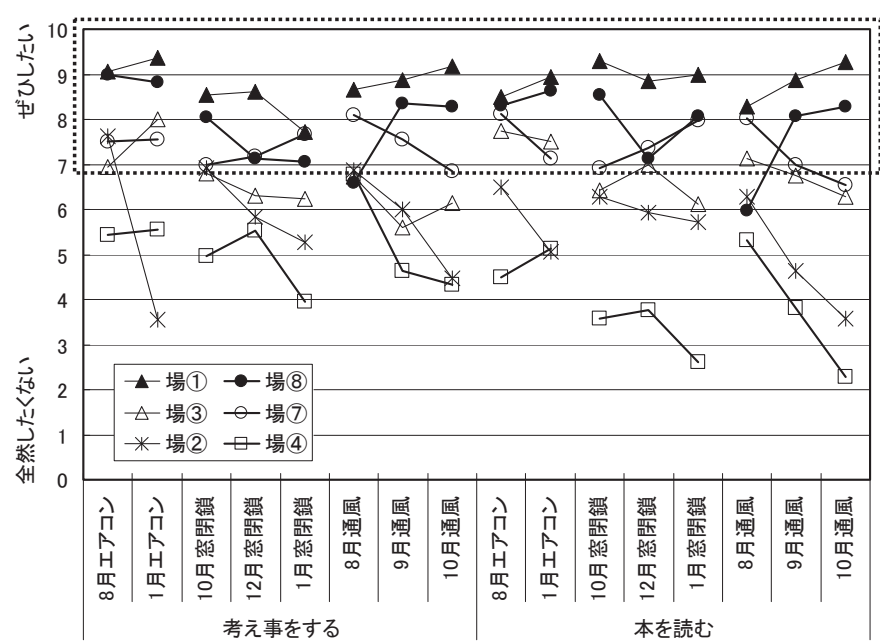

(c) 第 1 因子の『集中』の思考行為と視作業行為

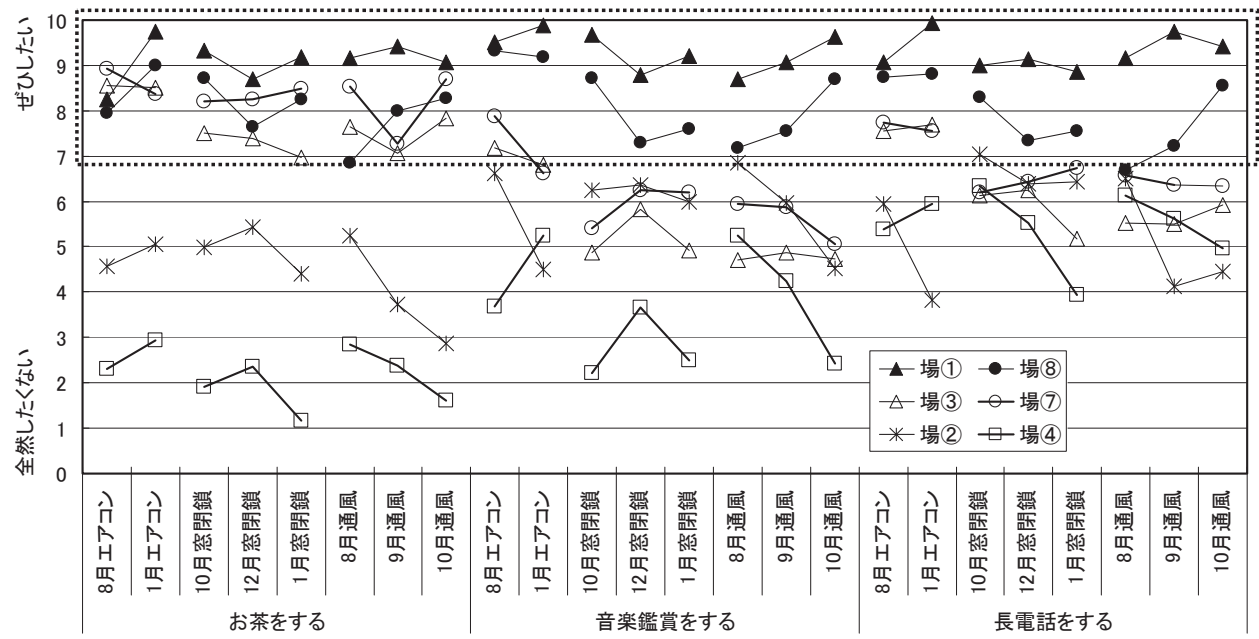

（b）第 1 因子の『リラックス』の娛楽行為

\section{（4）階段}

図 7 に、階段（場(4)）における第 1 因子の因子得点と SET*との関係を示 す。図 7 を見ると、1 月エアコン使用 条件と 8 月自然通風条件において他の 条件より高い值に得点が集まる傾向が 見られる。 8 月について通風の影響を 検討したところ、通風が評価を高めた と考えられる。また、エアコン使用条 件、空閉鎖条件、自然通風条件との実 験条件に関係なく、気温が低くなると ともに得点は広範囲で広がっている傾 向がある。場(4)は、直接階段のステッ プに座る場所である。そのため、ソフ アや椅子と階段ステップの熱伝導の特 性の違いが場(4)において気温が低い場

も見られる。

図 6 に、リビング床 (場(2) における第 1 因子の因子得点と SET* との関係を示す。まず、エアコン使用条件の 8 月（凡例： $\square$ ）と 1

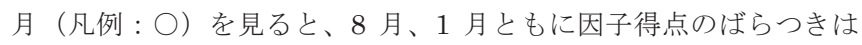
小さい。この傾向は、リビングソファとダイニング椅子の結果と一 致している。しかし、8 月の得点は高いが、1 月の得点は低い。 1 月のエアコン使用条件は、天気が曇りで、寒い日であった。そのた め、床の玄昌石が冷えたままであり、リビング床のみ、1 月のエア コン条件で評価が低かったのではないかと考えられる。空閉鎖条件 の 10 月、 12 月、 1 月では、エアコン使用条件に比べ、得点が少し ばらつく傾向が見られたが、それでも相対的に高い值となっている。 なお、 12 月と 1 月の空閉鎖条件では、リビング床（場(2) に直接日 射があたる。空に近い場所でも冷放射の影響はあまりなく、10月よ りも室温が高い点が多くなったと考えられる。次に自然通風条件の 8 月、 9 月、10月であるが、 8 月は得点が高い值に集まっているが、 9 月と 10 月は得点が非常に広い範囲に広がっている。 8 月は、風速 との関係を検討した結果、風速が大きくなるほど評価が高くなる傾 向が現れている。また、南面のつたかずらによる照り返しや天空日 射の遮へいの影響もあると思われる。
合に、因子得点が低い值となった一因であると考えられる。

以上から、第 1 因子『リラックス・集中』の行為は、エアコン使 用条件においてリビングソファとダイニング椅子で因子得点が最も 高いが、8月自然通風条件でも、高い SET*時に高得点が見られ、12 月、 1 月の空閉鎖条件でも広い $\mathrm{SET}^{*}$ 範囲で高得点が見られた。エア コン使用時は行為を快適に行える場所が多いが、自然環境要素を取 り入れることにより、エアコンを使わなくても、行為を快適に行え る場所を作ることができる。

\section{5. 季節ごと場所ごとの生活行為の評価}

前章で、『リラックス・集中』の行為のエアコン使用時は、リビン グソファ（場(1)と場 (8) ) とダイニング椅子（場(3)と場(7)）で高い得 点が多く見られることを述べた。しかし、自然環境要素を取り入れ た時は、季節によって場所の温熱環境が異なり、行為の因子得点に 違いが見られた。ここでは、各生活行為について季節ごとの選ばれ る可能性が高い場所について分析する。図 8～図 10 に因子分析から 得られた $3 つ の$ 行為群について、季節ごと場所ごとの行為の評価平 均值を示す。 


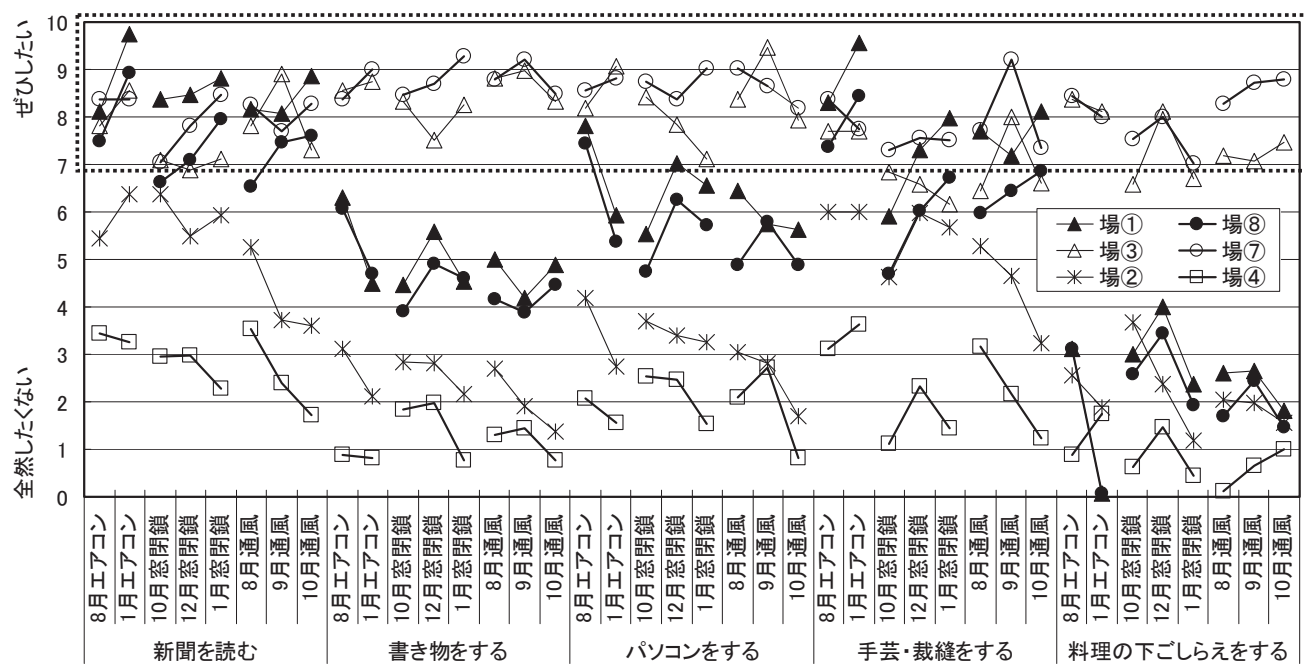

図 9 第 2 因子の『作業』の行為における季節ごと場所ごとの平均值

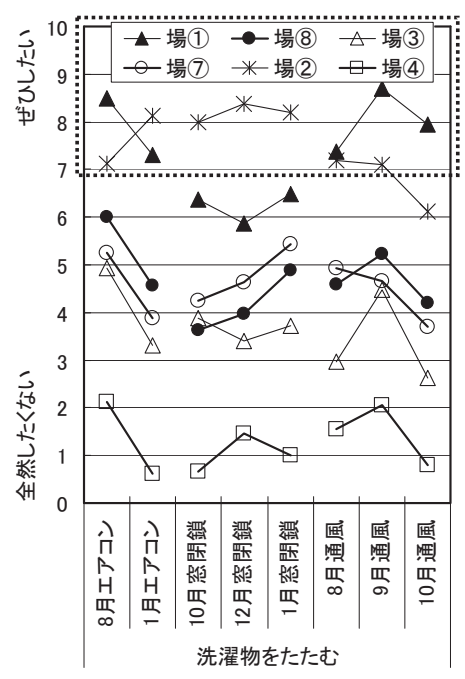

図 10 第 3 因子の『洗濯物』
図 8 の（a）に第 1 因子の『リラックス』の休㮩行為、(b) に第 1 因子の『リラックス』の娛楽行為、(c) に第 1 因子の『集中』の思 考行為と視作業行為を示寸。図 9 に第 2 因子の『作業』の行為、図 10 に第 3 因子の『洗濯物をたたむ』の行為を示す。評価得点が 7.0 点以上になると、行為を行う場所として選ばれる可能性が高いと判 断し、点線の枠で囲った。

まず、図 8 の（a）（b）（c）より、第 1 因子の『リラックス・集 中』の行為は、全体的に季節と条件に関係なく、8 月の自然通風条 件のリビング 1 人掛けソファの場(8)を除いて、リビングソファ（場 (1) と場 (8) で評価得点が高い。住宅内のリビングはそもそも休礊行 為を行えるよう、計画設計されるものであり、妥当な結果であると 考えられる。『リラックス・集中』の休款行為はエアコンを使用する と、ダイニング椅子 (場(3)と場(7) ) で評価が高いが、冬季の 12 月 と 1 月の空閉鎖条件と 8 月の自然通風条件でも評価得点が 7.0 点を 超える。図 8 (b) をみると、同じ娛楽行為の「お茶をする」の行為 は、ダイニング椅子 (場(3) と場(7) ) で高い評価得点が見られる。こ れは、テーブルがあると「お茶をする」の行為がよりしやすくなる のだと考えられる。また、夏季と冬季にリビング床の場(2)でも高い 得点が多数見られる。全体的に評価得点が低い階段の場(4)でも、8 月の自然通風条件は評価得点が高くなっている。これは、階段の場 (4)はリビングの南西空から遠いが、2 階への通風経路となっていた ためだと思われる。すなわち、ダイニング椅子（場(3)と場(7)）とリ ビング床（場(2)）と階段（場(4)）においても『リラックス・集中』 の休憩行為の評価は、季節によっては高い得点になっており、行為 の場所として選ばれる可能性が高い。

図 9 より、『作業』の行為はいずれも、ダイニング (場(3)と場(7) でどの季節でも評価得点が高く、反対に階段（場(4)）はどの季節で も評価得点が低い。すなわち、『作業』の行為は、何よりもまず作業 のしや寸さが優先されると考えられる。第 1 因子の負荷量が比較的 大きい「新聞を読む」と「手芸・裁縫をする」の行為は、ダイニン グテーブル（場(3)と場(7)）ではなく、リビングソファで最も高い得 点となる季節があり、季節によっては場所の選択が変わるといえる。

図 10 において、『洗濯物をたたむ』は、エアコンを使用するとリ ビング 1 人掛けソファの場(1)とリビング床の場(2)で 7.0 点以上の高
い得点が得られたが、空閉鎖条件ではリビング床（場(2)）が最も高 く、通風条件では 1 人掛けソファ（場(1)）が最も高い得点を取ると いう違いがある。

以上の結果から、第 1 因子の『リラックス・集中』は、リビング ソファが好ましい場所であるが、リビングソファだけでなく、リビ ング床（場(2)）、階段（場(4)）、ダイニング椅子（場(3)と場(7)）で得 点が高くなる時があり、季節の環境条件の変化によって『リラック ス・集中』を行う場所の選択肢が増える結果となっている。行為を 行う場所として計画されてない場所でも、温熱的な環境計画をうま く行うことによって行為を行える場所として選択される可能性が生 まれ、その結果、住宅空間で場所の自由度が高まり、「場所を楽しむ」 こととパッシブな住まい方を行うことができると思われる。第 2 因 子の『作業』の行為は、季節に関係なくダイニング椅子が好ましい 場所となるが、季節によってはリビングソファの場(8)でも好ましい 場所として選択されうる。

\section{6. おわりに}

自然環境要素を取り入れる室内空間では、季節により場所の温熱 環境が異なり、より快適に行為を行える場所が変化する可能性があ る。本報では、住宅の LDK 空間における日常の生活行為と温熱環 境条件との関係を明らかにすることを目的とした。具体的には、生 活行為の特徵を分類・整理すること、その生活行為と場所との関係 を明らかにすること、季節による場所ごとの温熱環境が場所ごとの 行為の評価に及ぼす影響を明らかにすることを目的としている。被 験者は「このモデルハウスに住んでいる主婦であり」、「主人と子供 は出かけていて家には一人でいる」という設定で心理評価と物理環 境測定を行った。その結果、以下の知見が得られた。

1）因子分析結果から、生活行為は第 1 因子『リラックス・集中』、 第 2 因子『作業』、第 3 因子『洗濯物をたたむ』の 3 つの因子で 説明できる。

2）第 2 因子の『作業』は、場所の温熱環境が変わっても因子得点 に大きい違いが見られず、それぞれの場所の空間的特徵が評価 に大きな影響を与えている。

3）一方、第 1 因子の『リラックス・集中』と第 3 因子の『洗濯物 
をたたむ』は場所による違いもあるが、季節の温熱環境要素の 相違によって因子得点が大きく異なる場合が見られた。

4）評価平均值の分析から、因子分析結果と同様に第 1 因子の『リ ラックス・集中』の行為の評価得点は、冷暖房を使用すると季 節に関係なくリビングソファ（場(1)と場 (8)）とダイニング椅子

(場(3)と場(7)）が好ましい場所となることがわかった。

5）さらに、評価平均值の分析から、『リラックス・集中』の行為 の得点は 8 月の自然通風のリビング 1 人掛けソファの場(8)を除 いて、リビングソファ（場(1)と場(8)）で季節に関わらず高い。

6）第 1 因子の『リラックス・集中』の行為は、リビング 1 人掛け ソファ (場 (8))、ダイニング椅子 (場(3)と場(7))、リビング床 (場 (2)）、階段（場(4)）において季節によって評価得点が高くなるこ とがあり、選択される可能性が生まれる。段階は本来通路であ るが通風などの環境計画によって『リラックス・集中』の行為 を行える場所となり、その結果、「場所を楽しむ」とともにパッ シブな住まい方を行うことにつながる可能性がある。

7）第 2 因子の『作業』の行為は、ダイニング椅子（場(3)と場(7) でどの季節も得点が高い。これは、温熱環境よりも作業をしや すいという場所の空間的特徴が評価に影響したと思われる。「新 聞を読む」と「手芸・裁縫をする」の行為はダイニングに加え て、リビングソファで高い得点が現われており、季節によって は場所の選択肢が増えることがわかった。

8）第 3 因子の『洗濯物をたたむ』の行為は、空閉鎖条件ではリビ ング床（場(2)）が最も高く、通風条件では 1 人掛けソファ（場

(1)）が最も高い得点を取るという違いが見られた。

建築計画的には場所によって行う行為がほぼ決まっている。しか し、以上の結果から、住宅計画で季節の自然環境要素を積極的に取 り入れることによって、季節ごとの場所の温熱環境が変わり、行為 を行える場所の選択肢が増えることにつながり、「場所を楽しむ」こ とを可能にする。建築計画の面を考慮しつつ、環境計画を行うこと によって、場所の選択肢が変化したり、増えたりし、冷暖房設備に 頼らずに、エネルギーを消費せず、快適で、パッシブな住まい方が できると考えられる。さらに、住宅における生活行為と場所の物理 環境に関するデータを蓄積することで、よりパッシブな住宅設計が 行えると考えている。

\section{謝辞}

本実験は柳原絵里子氏（名古屋大学卒業生）の全面的な協力を得 た。記して感謝の意を表す。

\section{注}

注1） 1 うたた寝をする: 寝るつもりはなくついうとうとと寝てしまうこと。 2 書き物をする: 手紙を書く・文章を書く・家計簿をつけることなど。 3 パソコンをする : ノートパソコンを持ち歩くという前提。 4 搽をする: コーヒー・紅茶を飲むこと、おやつを食べることなど。 5 音楽鑑賞をする : 集中して音楽を聴くこと、音楽を聴きながら、勉 強などをすることとは異なる行為。

6 長電話をする: コードレス子機や携帯で電話をするという前提。

7 手芸・裁縫をする : ボタン付けや刺紼など。

8 料理の下ごしらえをする：さやえんどうのすじをとる・つくしのは かまをとるなど、時間がないとなかなかできないこと、あまり污れ ないような作業。

注2）行為の評価の際には、各場所に座ってはいないが、場所の評価と温熱環
境の評価際には、各場所に座っている。

注3）場(5)（キッチン）と場(6)（作業台）は「うたた寝をする」を尋数なかっ たため、分析から外した。

注4）このモデルハウスは南面（空(11）に大きな空が取られているため、全体 的に照度が高く、照明の ON、OFF の影響が小さかった可能性がある。

\section{参考文献}

1）宇野浩三, 足達富士夫, 眞嶋二郎 : 公室空間の構成と生活形態一北海道 の戸建住宅における公室空間に関する研究 (1) - , 日本建築学会計画 系論文報告集, NO.401, pp.57-63, 1989.7

2）森ゆかり，出口寛子，柏原土郎：主婦の立場から見た食空間の現状とそ のあり方について〜家族の生活行為と食空間の分析〜, 日本建築学会大 会学術講演梗概集 E-2（中国）, pp.101-102, 2008.9

3）沖田富美子, 入澤敦子, 伊藤香織 : 住戸タイプと地域による家族生活空 間の比較研究 その $1 \sim 2$ 、日本建築学会大会学術講演梗概集 E-2（九 州), pp.189〜192, 1998.9

4）澤地孝男, 松尾陽, 羽田野健, 福島弘幸: 住宅の室内気候形成に寄与寸 る居住者の行動に関する研究 その 1 , 日本建築学会計画系論文報告集, NO.382, pp.48-59, 1987.12

5) Sawashima, T. and Matsubara, N. : Residents' Seasonal Changes of Place of Occupation in the House as Behavioral Thermoreguration, Journal of the Human-Environmental System, Vol.7, NO.1, pp.35-46, 2004

6）松原斎樹, 澤島智明: 京都市近辺地域における冬期住宅居間の熱環境と 居住者の住まい方に関する事例研究〜暖房機器使用の特徵と団らん時 の起居様式〜日本建築学会計画系論文集, NO.488, pp.75-84, 1996.10

7）澤島智明, 松原斎樹: 京都市近辺地域における冬期住宅居間の熱環境と 居住者の住まい方の季節差に関する研究〜住戸内での滞在場所洗濯行 動に与える温熱環境の影響〜日本建築学会計画系論文集, NO.507, pp.47-52, 1998.5

8）加藤友也, 山岸明浩, 山下恭弘 : 長野市を中心した一戸建住宅の冬季室 内温熱環境に関する調查研究一捏損失係数から見た室内温熱環境と居 住者意識の違いについて一, 日本建築学会計画系論文集, NO.470, pp.19- $27,1995.4$

9）加藤友也，山岸明浩，山下恭弘：長野市を中心した一戸建住宅の室内温 熱環境と居住者意識の冬季と夏季の差, 日本建築学会計画系論文集, NO.481, pp.23-31, 1996.3

10）高娟淑, 久野覚, 原田昌幸, 中山和美, 飯村 龍: 住宅における夏季の通 風と冬季の日射が室内温熱環境評価に及ぼす影響, 日本建築学会環境 系論文集，NO.638, pp.427-433, 2009.4

11）高娟淑, 原田昌幸, 久野覚 : 光・温熱環境の日変動・年変動を考慮した 暮らし方および室内環境設計法に関する研究一その 1 住宅の LDKにお ける空間の評価の季節変動, 日本建築学会大会学術講演梗概集 D-1（九 州) pp.117-118, 2007.7

12）高娟淑, 柳原絵里子, 原田昌幸, 久野覚, 中山和美, 飯村 龍 : 生活行 為を考慮した住宅の温熱環境評価に関する研究一その (2) 住宅 LDK に㧍ける室内空間評価に関する季節変動, 空気調和・衛生工学学会中部 支部学術研究発表会論文集, NO.9, pp.9-12, 2008.3

13）高娟淑, 朱方舟, 原田昌幸, 久野鸴, 中山和美, 飯村龍: 生活行為を考 慮した住宅の室内空間評価に関する研究一その 1 住宅LDKにおける温 熱環境評価に関する季節変動, 日本建築学会大会学術講演梗概集 D-1 (中国) , pp.27-28, 2008.9

14) Ko, Y., Kuno, S., Harada, M., Nakayama, K., Iimura, R., : The relation between place and action evaluation and indoor environmental conditions, Proceeding of the 2008 Korea-Japan Joint Conference, pp.59-62, 2008.11

15）高娟淑, 久野覚, 原田昌幸, 中山和美, 飯村龍 : 住宅 LDK における物 理環境と生活行為抢よび室内空間評価の関係に関する研究, 空気調和・ 衛生工学学会中部支部学術研究発表会論文集, NO.10, pp.61-65, 2009.3

(2009年 6 月 10 日原稿受理，2010年 7 月 15 日採用決定) 